\title{
EDUCAÇÃO NO CONTEXTO DAS MIGRAÇÕES E INTERCULTURALIDADE
}

\section{EDUCATION IN THE CONTEXT OF MIGRATION AND INTERCULTURALITY}

\section{LA EDUCACIÓN EN EL CONTEXTO DE LA MIGRACIÓN Y LA INTERCULTURALIDAD}

Nonato Assis de Mirandaㅁ ${ }^{1}$ Luciane Muniz Ribeiro Barbosa ${ }^{2}$

O terceiro número de 2021 da revista Educação Temática Digital - ETD é lançado com o propósito de trazer para o debate duas temáticas que não são novas, mas, em razão de sua relevância e até mesmo da complexidade inerente a elas, demandam discussões e reflexões em caráter permanente. Trata-se da interculturalidade e da imigração, bem como de seus impactos e desafios à educação.

Esse ponto de vista está pautado no entendimento de que os intercâmbios culturais entre sociedades têm sua gênese no início da história da humanidade, mais precisamente com a Grécia Clássica e o Império Romano, cujas evidências estão centradas, principalmente, nas inúmeras trocas e interações realizadas entre esses povos por meio do Mediterrâneo. Outro evento histórico que reitera o entendimento de que sempre houve contato entre as diferentes culturas é a expansão da Europa em direção à América e à África (CANCLINI, 2006).

Em razão de seu caráter contínuo, desde então, a mobilidade de pessoas mundo afora tem se constituído numa prática milenar da humanidade. Todavia, por razões diversas, mais recentemente esse fenômeno tem obtido uma visibilidade muito grande nos meios de comunicação cuja imagem que, a princípio, buscam imprimir é a de que se trata de um acontecimento recente e descontrolado. Não obstante, para além do olhar simplista sobre esse fenômeno, é oportuno sinalizar que, muito provavelmente, a novidade esteja na diversidade das atuais categorias de migrantes: "econômicos, expatriados, refugiados,

\footnotetext{
${ }^{1}$ Doutor em Educação - Universidade Estadual de Campinas (UNICAMP). Campinas, SP - Brasil. Professor titular e Coordenador do Programa de Pós-Graduação em Educação - Universidade Municipal de São Caetano do Sul (USCS). São Paulo, SP - Brasil. Coordenador Geral do Curso de Pedagogia da Universidade Paulista (UNIP). São Paulo, SP - Brasil. E-mail: mirandanonato@uol.com.br

${ }^{2}$ Doutorado em Educação - Faculdade de Educação da Universidade de São Paulo (USP). São Paulo, SP - Brasil. Professora da Faculdade de Educação - Universidade Estadual de Campinas (UNICAMP). Campinas, SP - Brasil. E-mail: lumuniz@unicamp.br
}

(C) ETD-Educação Temática Digital Campinas, SP v.23 n.2 p.572-575 jul./set.2021


requerentes de asilo indocumentados, trabalhadores transfronteiriços, trabalhadores sazonais, binacionais, estudantes etc." e não no fato em si da mobilidade humana (SILVA; DI PIERRO, 2021, p. 4).

Com relação à interculturalidade, cabe salientar que se trata de uma vertente do multiculturalismo anglo-saxão presente nos países Latino-americanos e latinos da Europa, notadamente, Portugal, Espanha, França e Itália. Todavia, ela assume diferentes perspectivas considerando o contexto no qual se insere. Nos países do continente europeu, o dilema da interculturalidade é empregado para tratar dos desafios da "integração" da população imigrante de origem africana e americana, mas não exclusivamente, pois a Europa recebe pessoas de diferentes países. Por sua vez, na América Latina, as discussões sobre a interculturalidade estão associadas aos povos indígenas, mas, diferentemente do que acontece na Europa, não são populações estrangeiras e sim "[...] uma população originária que habitava o continente antes do processo de colonização e da posterior formação dos atuais Estados Nacionais" (REPETTO, 2019, p. 71).

Essa diferença de perspectiva é muito interessante para compreender os diferentes campos de significados. Além disso, ela permite encontrar caminhos alternativos para busca de soluções com foco no enfrentamento dos desafios da interculturalidade em âmbito educacional.

Isso se faz necessário porque a escola de educação básica no Brasil, assim como na América Latina como um todo, tem sido objeto de políticas públicas que focalizam a cultura da avaliação e da meritocracia (CANDAU, 2016; MIRANDA; GARCIA; VERASZTO, 2020). Desse modo, não raro, tem-se investido no treinamento dos alunos para a realização de testes padronizados em Língua Portuguesa e Matemática na perspectiva do reducionismo curricular, desconsiderando, portanto, a diversidade dos estudantes presentes nas escolas de educação básica, assim como a interculturalidade.

Entendemos que esse cenário é preocupante, porque além de haver evidências de que ele não funciona (RAVICH, 2011), tende a excluir ainda mais os estudantes, especialmente aqueles tidos como "diferentes", que não se adequam a esse modelo.

Por outro lado, há a defesa de que

A educação intercultural parte da afirmação da diferença como riqueza. Promove processos sistemáticos de diálogo entre diversos sujeitos - individuais e coletivos saberes e práticas na perspectiva da afirmação da justiça - social, econômica, cognitiva e cultural -, assim como da construção de relações igualitárias entre grupos socioculturais e da democratização da sociedade, através de políticas que articulam direitos da igualdade e da diferença (CANDAU, 2014, p. 1). 
Ao adotarmos a diferença como riqueza e não como um problema a ser resolvido, vemos a educação intercultural como possibilidade de ampliação das experiências em prol de um mundo menos desigual, mais equânime e, portanto, mais inclusivo. Mas temos consciência de que esse olhar se torna factível somente quando desconstruímos "[...] aspectos da dinâmica escolar naturalizados que nos impedem de reconhecer positivamente as diferenças culturas e, ao mesmo tempo, promover processos que potencializem essa perspectiva (CANDAU, 2016, p. 809).

Dentre outras, uma forma de fomentar essa desconstrução é por meio da apropriação teórica de temas inerentes à interculturalidade e à imigração levando em consideração seu processo histórico, assim como seus impactos no âmbito da educação escolar e universitária, mas não exclusivamente. É oportuno salientar que o fenômeno das migrações não se trata de uma questão exclusivamente educacional, pois tem implicações em outras áreas do conhecimento, assim como da atuação humana.

Em face ao exposto, convidamos você a fazer uma leitura do Dossiê "Interculturalidade e imigração: impactos e desafios à educação", proposto pelos professores pesquisadores brasileiros Elcio Cecchett e Adecir Pozzer e pelo espanhol José María Hernández Díaz. Dentre os sete artigos publicados neste dossiê, quatro estão escritos em espanhol e três em língua portuguesa, apresentando, no seu conjunto, resultados de pesquisa, assim como ensaios literários que focalizam aspectos da educação intercultural na Espanha e no Brasil, considerando as diferentes formas de conceber esse fenômeno em face dos contextos em que o tema é analisado.

Assim como os propositores, acreditamos que os artigos deste dossiê permitirão a diferentes públicos de leitores a reflexão e o debate sobre questões inerentes à interculturalidade e às imigrações, considerando seus impactos e desafios para a educação.

Neste mesmo número da Revista estão disponíveis outros seis artigos de demanda contínua que, em certa medida, também exploram, sob diferentes perspectivas, desafios complexos para a área da educação ao problematizarem temáticas relacionadas à corporeidade, gênero e padrão de beleza, projetos de vida de jovens com cegueira, formação humana integral, informática e tecnologias digitais na escola, entre outras.

Enquanto o mundo se volta para os impactos do isolamento social causado pela pandemia que marca(rá) o início do século XXI, convidamos os leitores e leitoras da ETD a migrarem os olhares e análises para temas históricos que, ao mesmo tempo, também se revelam atuais e necessários. Enfim, desejamos uma excelente leitura e imersão nas reflexões propostas por este número!

(C) ETD-Educação Temática Digital Campinas, SP $\quad$ v.23 $\quad$ n.2 $\quad$ p.572-575 jul./set.2021 


\section{REFERÊNCIAS}

CANDAU, Vera Maria. Concepção de educação intercultural. Rio de Janeiro: PUC-Rio, 2014.

CANDAU, Vera Maria. Cotidiano escolar e práticas interculturais. Cadernos de Pesquisa v.46, n.161, p.802-820, jul./set. 2016.

CANCLINI, Nestor Garcia. Culturas Híbridas. São Paulo: Editora da Universidade de São Paulo, 2006.

MIRANDA, Nonato Assis de; GARCIA, Paulo Sérgio; VERASZTO, Estéfano Vizconde. Avaliação em larga escala e seus efeitos na gestão escolar: a concepção dos diretores. Rev. FAEEBA Ed. e Contemp., Salvador, v. 29, n. 57, p. 251-268, jan./mar. 2020.

RAVITCH, Diane. Vida e morte do grande sistema escolar americano: como os testes padronizados e o modelo de mercado ameaçam a educação. Porto Alegre: Sulina, 2011.

REPETTO, Maxim. Dossiê o conceito de interculturalidade: trajetórias e conflitos desde américa latina. Textos e Debates, Boa Vista, n.33, p. 69-88, jul./dez. 2019

SILVA, Rita de Cássia da Cruz; DI PIERRO, Maria Clara. Os impactos da covid-19 nas migrações internacionais e na efetivação de direitos educativos de migrantes e refugiados adultos - notas de pesquisa. Ciências Humanas, Pré-print (2021). Disponível em: https://preprints.scielo.org/index.php/scielo/preprint/view/1942/version/2061. Acesso em: 23 jul. 2021. 